\title{
Immunogenicity of Personalized Dendritic-cell Therapy in HIV-1 Infected Individuals Under Suppressive Antiretroviral Treatment: Interim Analysis From a Phase II Clinical Trial.
}

\section{Marcela Vassão de Almeida Batista}

Federal University of São Paulo

Laís Teodoro Silva

Federal University of São Paulo

\section{Sadia Samer}

Federal University of São Paulo

Telma Miyuki Oshiro

Federal University of São Paulo

lart Luca Shytaj

Federal University of São Paulo

\section{Leila Giron}

Federal University of São Paulo

\section{Nathalia Mantovani Pena}

Federal University of São Paulo

Nicolly Cruz

Federal University of São Paulo

\section{Gisele Cristina Gosuen}

Federal University of São Paulo

\section{Paulo Roberto Abrão Ferreira}

Federal University of São Paulo

\section{Edécio Cunha Neto}

Federal University of São Paulo Juliana Galinskas

Federal University of São Paulo

Danilo Dias

Federal University of São Paulo

Maria Cecilia Araripe Sucupira

Federal University of São Paulo

\section{Cesar Almeida-Neto}

Federal University of São Paulo 


\section{Reinaldo Salomão}

Federal University of São Paulo

Alberto José da Silva Duarte

Federal University of São Paulo

Luís Mário Janini

Federal University of São Paulo

James $\mathbf{R}$ Hunter

Federal University of São Paulo

Andrea Savarino

Federal University of São Paulo

Maria Aparecida Juliano

Federal University of São Paulo

Ricardo Sobhie Diaz ( $\nabla$ rsdiaz@catg.com.br)

Federal University of São Paulo https://orcid.org/0000-0002-8395-7304

\section{Research}

Keywords: Dendritic cell therapy, HIV GAG, HLA Haplotypes, HIV cure research, Precision Medicine

Posted Date: September 14th, 2021

DOI: https://doi.org/10.21203/rs.3.rs-869990/v1

License: (c) (i) This work is licensed under a Creative Commons Attribution 4.0 International License. Read Full License 


\section{Abstract}

\section{Background}

We developed a personalized Monocyte-Derived Dendritic Therapy (MDDCT) for HIV-infected individuals on suppressive antiretroviral treatment and evaluated HIV-specific T-cell responses.

\section{Methods}

PBMCs were obtained from $10 \mathrm{HIV}^{+}$individuals enrolled in trial NCT02961829. Monocytes were differentiated into DCs using IFN- $a$ and GM-CSF. After sequencing each patient's HIV-1 Gag and determining HLA profiles, autologous Gag peptides were selected based on the predicted individual immunogenicity and used to pulse MDDCs. Three doses of the MDDCT were administered every 15 days. To assess immunogenicity, patients' cells were stimulated in vitro with autologous peptides, and intracellular IL-2, TNF, and interferon-gamma (IFN- $\gamma$ ) production were measured in CD $4^{+}$and $\mathrm{CD} 8^{+} \mathrm{T}^{-}$-cells.

Results

The protocol of ex-vivo treatment with IFN-a and GM-CSF was able to induce maturation of MDDCs, as well as to preserve their viability for reinfusion. MDDCT administration was associated with increased expression of IL- 2 in $\mathrm{CD} 4^{+}$and $\mathrm{CD} 8^{+}$T-cells at 15 and/or 30 days after the first MDDCT administration. Moreover, intracellular TNF and IFN- $\gamma$ expression was significantly increased in CD $4^{+}$T-cells. The number of candidates that increased in vitro the cytokine levels in $\mathrm{CD} 4^{+}$and $\mathrm{CD} 8^{+} \mathrm{T}$ cells upon stimulation with Gag peptides from baseline to days 15 and from baseline to days 30 and days 120 after MDDCT was significant as compared to Gag unstimulated response. This was accompanied by an increasing trend in the frequency of polyfunctional T-cells over time, which was visible when considering both cells expressing two and three out of the three cytokines examined.

\section{Conclusions}

MDDC has a mature profile, and this MDDCT promoted in-vitro T-cell immune responses in HIV-infected patients undergoing long-term suppressive antiretroviral treatment.

NCT02961829: (Multi Interventional Study Exploring HIV-1 Residual Replication: a Step Towards HIV-1 Eradication and Sterilizing Cure, https://www.clinicaltrials.gov/ct2/show/NCT02961829, posted November $\left.11^{\text {th }}, 2016\right)$.

\section{Introduction}

The onset of HIV-1 infection induces a robust immune response by the host $(1,2)$. However, this response does not typically lead to immunological control of the infection, as shown by the rapid rebound of viremia after interruption of antiretroviral treatment (ART) (3-7). Of note, the extent of post-therapy viral 
load rebound is proportional to the size of the HIV-infected cellular reservoir, and the size of this reservoir is in turn proportional to the length of the period during which the infection progresses without ART (7).

Pivotal for the immune response, dendritic cells (DC) are professional antigen presenters. These cells are anatomically positioned as sentinels for detecting danger signals, thus triggering an innate and adaptive immune response (8). DCs can migrate to lymph nodes and other HIV-1 sanctuaries and, once activated, produce interleukins such as IL-12, IL-15, and IL-18, promoting a potent cytotoxic T-cell response necessary for the elimination of infected cells. Due to these characteristics, therapy approaches based on DCs have been proposed and tested to modulate the host's immune response to HIV-1 infection $(3,9-20)$.

DC-based therapy relies on in-vitro pulsing or electroporating of autologous monocyte-derived DCs (MDDCs) with whole inactivated HIV-1, with RNA coding for viral antigens (12), or with specific sets of peptides $(9,11)$, to induce recognition of viral epitopes by the individual's human leukocyte antigens (HLAs) on the DC surface. Peptide-pulsed DCs are then reinfused into the donor to provide an appropriate antigenic stimulus within the body when retroviral replication is still suppressed by ART. While MDDC therapy (MDDCT) has been typically administered to HIV-infected individuals under ART, the virus used for MDDCT design or preparation was obtained from samples of treatment-naive individuals. This choice was determined by the presence of a high percentage of defective viruses in cells of patients under longterm ART, rendering difficult the isolation and in-vitro expansion of high amounts of replication-competent HIV-1 $(21,22)$. HIV-1 peptides typically employed in MDDCT design have been derived from highly conserved proteins of HIV-1, i.e., Gag, Pol, and $\operatorname{Nef}(9,11)$. Moreover, conserved portions of variable antigens such as Env have been considered $(14,15)$. After infusion, the therapeutic efficacy of the MDDCT is assessed by interrupting ART to check whether viral load suppression can be maintained in the absence of drugs $(10,11,15,18,19)$. Moderate post-therapy efficacy was observed in some of these studies $(10,18)$. In particular, an MDDCT strategy based on Gag, Pol, and Nef antigens, was associated with a post-therapy decrease of the viral load set point of one order of magnitude in a subset of patients (11). However, in this case, and all other MDDCT studies reported so far, post-therapy viral load control was not comparable to that exerted by ART. Although this and other results have suggested that DCbased MDDCTs, if improved, might become an essential therapeutic tool, the correlates of immune control of viral load in the MDDCT responder subpopulation have remained unclear. One possible limitation of the approaches tested so far is using a standardized MDDCT design, administered to all patients independently of their HLA genotype. Given the degree of HLA polymorphism worldwide (23), individual variability can significantly impact immune recognition.

Another potential limitation in the design of the MDDCTs attempted so far is the choice of antigens used for immunization. Indeed, correlation studies between cell-mediated immunity and HIV-1 viral load control suggest that a narrower selection of viral proteins as MDDCT targets might be preferable. In particular, the viral capsid Gag protein represents an attractive target since anti-Gag cell-mediated immunity was repeatedly highlighted as the main immunological correlate of reduced viral load and decreased disease progression (24-29). Additional evidence suggests that latently HIV-1 infected cells, which are the main obstacle to the cure of HIV-1, express low levels of the Gag protein and could thus be detected and 
eventually eliminated by Gag-specific cytotoxic T-lymphocytes $(30,31)$. The particular efficacy of anti-Gag immunity is likely determined by the structural role of the main maturation product of Gag, i.e., the viral core protein p24, which is the building block of the HIV-1 capsid (32). Several constraints lock p24 within the icosahedral capsid structure, limiting its capability to mutate $(33,34)$ without, however, abrogating it entirely (35). Apart from being less effective, cell-mediated immune responses directed against viral targets other than Gag might contribute to immune hyperactivation and exhaustion (36). Moreover, preexisting cell-mediated immune responses against different viral antigens might hamper MDDCT efficacy.

For this reason, an appropriate conditioning regimen, erasing some of the previously acquired immunity, could constitute a valuable addition to MDDCT. In this regard, lymphorestrictive approaches in the setting of chronic diseases characterized by malignant immune hyperactivation, such as HIV/AIDS or cancer, may paradoxically result in enhanced cell-mediated responses against the diseased cells $(37,38)$. Of note, none of the MDDCT approaches attempted so far have been associated with any conditioning regimen.

Given these premises, we designed and tested a personalized MDDCT using autologous HIV Gag peptides from patients undergoing long-term suppressive ART to decrease the reservoir of HIV-infected cells. This MDDCT was administered in the context of a larger clinical trial (clinicaltrials.gov ID: NCT02961829) which also examined the effects of a conditioning regimen consisting of auranofin to decrease the central memory T-cell pool encompassing the viral reservoir (39-41)) and nicotinamide, favoring HIV escape from latency to facilitate recognition of the HIV-infected cells $(42,43)$. To assess the immunogenicity of our personalized MDDCT strategy and help guide the choice of analytical treatment interruption (ATI) in a larger planned trial, we performed an interim analysis of immunologic parameters in the MDDCT recipients.

\section{Materials And Methods}

\section{The general plan of the study}

Between February 2015 and May 2016, 10 chronically HIV-1-infected patients were included in treatment arms 5 and 6 of the SPARC-06 Clinical Trial (NCT02961829) to receive an autologous MDDCT without (group 5) or with (group 6) a conditioning regimen consisting of nicotinamide and auranofin (39). We enrolled males $\geq 18$ years under suppressive ART with undetectable viral load for more than two years without virologic failure (Table 1). CD $4+$ T-cell counts at enrollment were above $500 \mathrm{cells} / \mathrm{mm}^{3}$, and CD $4^{+}$ T-cell count nadir was above 350 cells $/ \mathrm{mm}^{3}$. MDDCT was performed in the study candidates after the first 48 weeks of the intervention period in three doses at baseline (time zero), fifteen days after the first dose, and 30 days after the first dose. There were two significant deviations from the protocol (see Results section). All patients had undetectable viral load upon MDDCT administration except for the two protocol violators (P21 and P30, Table 1), which were viremic and not receiving ART during MDDCT administration. 
To avoid any effect of auranofin and nicotinamide on MMDDC function, auranofin was interrupted 24 weeks before and nicotinamide immediately before the MDDCT.

\section{MDDCT design}

We designed personalized peptides for pulsing of MDDCs, following a multi-step approach for each study candidate. As a first step, each patient's HIV-1 gag sequence was characterized from peripheral blood mononuclear cell (PBMCs) DNA through the generation of genomic sequences after clonal amplification of viral strains through Next Generation Sequencing (NGS) and single genome amplification. For single genome amplification, at least ten clones were generated per patient, as previously described (44). In the second step, the HIV DNA sequences were translated to amino acid sequences. Briefly, the three frames of translation were aligned to the start of Gag in the HXB-2 reference sequence to determine the correct reading frame using Clustal-Omega (45). The polypeptides obtained were edited by manual correction, i.e. tryptophans were used to replace spurious stop codons in the middle of the sequence. Clustal-Omega was also used to create a consensus sequence. Additional alignments were then made using the published aligned sequences to map the highly conserved regions of the consensus Gag sequences from each study subject.

In parallel, HLA haplotypes of the same individuals were sequenced. HLA A, B, C, and DR typing was done by sequence-specific oligonucleotide methodology using a LUMINEX 200 apparatus. Briefly, DNA was extracted from the buffy coat of EDTA- anticoagulated peripheral blood with the Qiamp DNA mini kit (Qiagen) and subjected to One lambda LAbtype SSO (Thermo Fisher) according to the manufacturers' instructions.

Finally, the selection of HIV-1 Gag epitopes was performed by designing peptides from the autologous HIV gag sequence and selecting those predicted to be recognized by each individual's MHC Class I and Class II. The epitopes were predicted using the NetMHCpan v4.0 server (46), which displays an overall accumulated prediction ranking score of 49-78 (47)), as calculated between 2018 and 2021 by The Immune Epitope Database (IEDB) (48)). A number of peptides were selected in positions encompassing amino acids 256-377 of the Gag polypeptide. Those peptides containing more than one cysteine were discarded wherever possible to avoid internal disulfide bonds. The number of peptides designed for each candidate depended on the patients' affinity for multiple HLA haplotypes. Therefore, the higher the number of HLAs predicted to be bound by each peptide, the lower the number of Gag peptides for each candidate. Also, the number of peptides was chosen to keep the immunizing stimuli to a minimum. For example, peptides predicted to bind to multiple HLA haplotypes were preferred over those recognized by a single epitope: to minimize the synthesis costs and to ensure the maximum level of sequence conservation, preference was given to those peptides recognized by the haplotypes of more than one individual. For individuals for whom at least two peptides theoretically binding with high-affinity to more than one of their haplotypes were not found, a higher number of peptides, including peptides outside those above mentioned highly conserved regions, were designed, in order to increase the likelihood of immune recognition. In this manner, we designed 2 to 6 peptides (9-mers) per candidate, as shown in Supplementary Table 1. After MDDCT administration, NetMHCpan predictions were reanalyzed using the 
newly developed Custommune software (49)), which is validated based on documented biological data from the Los Alamos database (50)). The results were used to stratify patients' ex-post based on the concordance between software predictions (51).

\section{Peptide synthesis}

An automatic desktop synthesizer (PSSM 8 of Shimadzu) was used for the simultaneous solid-phase synthesis of all peptides using the Fmoc procedure. The final peptides were "unprotected" in TFA and purified by HPLC semi-preparation using an Econosil C-18 column $(10 \mu \mathrm{m}, 22,5 \times 250 \mathrm{~mm})$ and a system of two solvents: (A) trifluoroacetic acid (TFA) / $\mathrm{H}_{2} \mathrm{O}$ (1: 1000) and (B) TFA / acetonitrile (ACN) / $\mathrm{H}_{2} \mathrm{O}$ (1: 900: 100). The column was eluted at a flow rate of $8 \mathrm{~mL} / \mathrm{min}$ with a gradient of 0 to $80 \%$ of solvent $B$ for 45 minutes. The HPLC analysis was done using a binary HPLC system made by Shimadzu with a UV-vis detector SPD-10AV (Shimadzu), coupled to an Ultrasphere C-18 column $(5 \mu \mathrm{m}, 4,6 \times 150 \mathrm{~mm})$ that was eluted with system solvents $\mathrm{A} 1$ (TFA / $\mathrm{H}_{2} \mathrm{O}, 1:$ 1000) and $\mathrm{B} 1$ (ACN / $\left.\mathrm{H}_{2} \mathrm{O} / \mathrm{TFA}, 900: 100: 1\right)$ at a flow rate of $1.0 \mathrm{~mL} / \mathrm{min}$ and a gradient of $10-80 \%$ of $B 1$ for 10 minutes. The eluates of the HPLC columns were monitored for their absorbance at $220 \mathrm{~nm}$. The molecular weight and the purity of the synthesized proteins were verified by electron spray (LC / MS-2010 Shimadzu). The number of peptides was determined by analyzing the amino acids (Shimadzu).

\section{MDDC production}

The collection of MDDC precursor cells was carried out by leukapheresis with the cell separator Terumo Cobe Spectra at the Blood Center of São Paulo, São Paulo, Brazil. The total blood volume was calculated for each participant, and 1.5 total blood volumes were processed, in peripheral venous access, with continuous flow, at a speed of $50-60 \mathrm{~mL} / \mathrm{min}$. After the end of the collection, the leukapheresis product was sent to the Retrovirology Laboratory of the Federal University of Sao Paulo for the separation of monocytes and subsequent differentiation into DCs. Mononuclear cells from leukapheresis products were separated by Ficoll-Hypaque Premium (GE Healthcare ${ }^{\circledR}$ BioSciences, PA, USA) density gradient centrifugation and were cryopreserved in aliquots of $5 \times 10^{7}$ cells $/ \mathrm{mL}$ in liquid nitrogen using fetal bovine serum (FBS; Gibco Life Technologies ${ }^{\circledR}$, CA, USA) with $10 \%$ dimethyl sulfoxide (DMSO; Merck, Darmstadt, $\mathrm{HE}, \mathrm{DEU}$ ) until further assays were performed. Before use, cells were thawed at $37^{\circ} \mathrm{C}$ in a water bath and seeded at $5 \times 10^{6} / \mathrm{mL}$ in $175 \mathrm{~cm}^{2}$ tissue culture flasks (Corning ${ }^{\circledR}$ - Merck, Darmstadt, HE, DEU) in RPMI 1640 medium (Gibco Life Technologies) for two h at $37^{\circ} \mathrm{C}$ in a $5 \% \mathrm{CO}_{2}$ incubator to obtain adherenceisolated monocytes. After incubation, non-adherent cells were removed by washing, and the remaining cells (predominantly monocytes) were differentiated in MDDCs. To this aim, we compared two different procedures to select and optimize the most efficient protocol. In particular, we compared a protocol using IL-4 initially and GM-CSF followed by TNF, IL-1 $\beta$, and IL-6 (henceforth, IL-4 protocol; Supplementary Fig. 1A) with a protocol using IFN-a initially and GM-CSF, followed by LPS (henceforth, IFN-a protocol; Supplementary Fig. 1B). Briefly, in the IL-4 protocol, adherent cells were cultured in AIM-V medium (Therapeutic Grade - Gibco Life Technologies) in the presence of $50 \mathrm{ng} / \mathrm{ml}$ recombinant human Granulocyte-macrophage colony-stimulating factor (GM-CSF; Cell-Genix ${ }^{\circledR}, \mathrm{NH}, \mathrm{USA}$ ) and $50 \mathrm{ng} / \mathrm{ml}$ recombinant human IL-4 (Cell-GenixR, NH, USA) for five days, so as to obtain immature MDDCs 
(iMDDCs). On day 5, iMDDCs were pulsed with a pool of personalized HIV peptides that was added to the cells $(0.2 \mu \mathrm{g} / \mathrm{mL}$ each peptide) overnight. Later, the cells were washed to remove unbound peptide particles and were cultured for an additional two days in an AIM-V medium supplemented with the maturation cytokines IL-6 $(100 \mathrm{ng} / \mathrm{ml}), \mathrm{IL}-1 \beta(10 \mathrm{ng} / \mathrm{ml})$, and TNF $(50 \mathrm{ng} / \mathrm{ml})$, plus GM-CSF $(50 \mathrm{ng} / \mathrm{ml})$ and IL-4 (50 ng/ml; all from Cell-Genix), so as to obtain mature MDDCs (mMDDCs) pulsed with autologous peptides (Supplementary Fig. 1A).

In the IFN-a protocol, adherent cells were cultured in AIM-V medium to which GM-CSF and $500 \mathrm{IU} / \mathrm{mL}$ IFN$\mathrm{a}-2 \mathrm{~b}$ (Miltenyi Biotec, Auburn, CA, USA) were added on days 0 and 1 to obtain iMDDCs. On day 2, a pool of personalized HIV peptides was added to the cells $(0.2 \mu \mathrm{g} / \mathrm{mL}$ each peptide) overnight. The following day, six $\mathrm{h}$ before cell harvest, maturation of iMDDCs was induced by adding $5 \mathrm{IU} / \mathrm{mL}$ lipopolysaccharide (LPS-SM, Ultrapure InvivoGen, San Diego, CA, USA). After the incubation period, mMDDCs were recovered on ice and washed three times with sodium chloride solution $(0.9 \% \mathrm{NaCl}$, USP grade; Hospira, Lake Forest, IL) (Supplementary Fig. 1B).

Before reinfusion in patients, both iMDDCs and the final MDDCT were subjected to quality controls and immunophenotyping by flow cytometry analysis. For validation tests of DC maturation protocols, cell mortality was assessed using the cell viability kit (BD Biosciences) according to the manufacturer's recommendations. For assessing the viability of MDDCs before MDDCT administration, the aminereactive fixable LIVE/DEAD stain (Gibco Life Technologies, OR, USA) was used, by staining for $30 \mathrm{~min}$ at $4^{\circ} \mathrm{C}$. For further staining, after thorough washing with phosphate-buffered saline (PBS), cells were incubated for $20 \mathrm{~min}$ at $4^{\circ} \mathrm{C}$ and assayed using the following monoclonal antibody panel: CD11C APC or V450 (clone B-ly6), CD14 Pacific Blue (clone M5E2), HLA-DR FITC (clone G46-6), CD80 PE (clone L307.4), CD86 FITC (clone 2331 FUN-1) and CCR7 PerCP (clone 150503). All the mAbs were obtained from BD Biosciences ${ }^{\circledR}, C A$, USA, except CCR7 (R\&D Systems ${ }^{\circledR}, M N$, USA). Subsequently, cells were washed with FACS buffer ( $0.2 \%$ albumin and $0.1 \%$ sodium azide in PBS) and then fixed with $2 \%$ paraformaldehyde in PBS. Data were acquired on an LSR Fortessa Flow Cytometer (BD Biosciences) using the DIVA software, and the analysis was performed with FlowJo vX 0.7 software (Tree Star®, OR, USA).

\section{MDDCT immunogenicity analysis}

The effect of MDDCT on specific anti-HIV immune response in treated patients was assessed in patients' PBMCs collected from total blood on days $0,15,30$ (i.e., upon each dose of therapeutic immunization), and 120 (i.e., post-immunization follow-up). Total blood was drawn before each MDDCT dose to avoid confounding effects of MDDCT on each baseline. For this purpose, cells were plated at a concentration of $1 \times 10^{6} / \mathrm{mL}$ in 96 -well round-bottomed plates in $200 \mu$ of RPMI 1640 medium plus $10 \%$ FBS. Cells were either left unstimulated or incubated with $1 \mu \mathrm{g} / \mathrm{mL}$ of personalized peptides for $48 \mathrm{~h}$ in an incubator at $37^{\circ} \mathrm{C}$ and $5 \% \mathrm{CO}_{2}$. Six hours before cell harvest, the positive control wells $\left(\mathrm{C}^{+}\right)$were stimulated with 1 $\mu \mathrm{g} / \mathrm{mL}$ staphylococcal enterotoxin B (SEB, Merck OR, USA). After one h stimulation with SEB, $20 \mu \mathrm{g} / \mathrm{mL}$ of Brefeldin A (BFA, Merck) was added to the plate to block any further protein transport. Background 
controls $\left(\mathrm{C}^{-}\right)$consisted of PBMCs cultured in the absence of peptides and were used as blank, i.e., subtracted from the percentage of cytokine-producing lymphocytes obtained from wells incubated with the peptides. To evaluate immune responses/activation, PBMCs were first fixed and permeabilized using the Cytofix/Cytoperm and Perm/Wash kits (BD Biosciences CA, USA), following the manufacturer's recommendations. Cells were then incubated with a fixable live/dead stain (Gibco Life Technologies OR, USA) to check their viability and stained with a panel of antibodies including a-CD3 (V450; clone UCHT1), a-CD4 (BV605; clone RPA-T4), and a-CD8 (APC-H7; clone SK1) as well as antibodies against the intracellular cytokines IFN-y (PerCP-Cy5.5; clone B27), TNF (PE-Cy7; clone MAb11), and IL-2 (FITC; clone MQ1-17H12) (all from BD Biosciences CA, USA). Data acquisition was performed on an LSR Fortessa Flow Cytometer, using the DIVA software, and the analysis was performed with FlowJo vX 0.7. All samples and controls were analyzed in triplicate.

\section{Proviral DNA quantitation in Rectal biopsies}

Viral DNA was measured as an estimate of the viral reservoir by qPCR as previously described. (52)(53) (54)

\section{Data analysis}

Comparisons between two groups were conducted by chi-square testing, relative risk analysis and nonparametric Wilcoxon test. Comparisons between more than two groups were conducted by one-way ANOVA, followed by Dunnet's post-test, or by two-way ANOVA followed by Tukey's post-test. When appropriate, a logit transformation was applied to the data to restore normality before the statistical test. To allow for paired statistical analysis of the differences, patients with a missing value in a time point were excluded from that specific statistical analysis, but all available values were included when plotting the overall data. All analyses were conducted using the Prism v.6 software (GraphPad® Software Inc, CA, USA).

\section{Results}

\section{Optimization of MDDCT production}

To optimize the preparation of MDDCs, we initially tested two different protocols (i.e., IL-4 based and IFNa based) in terms of differentiation and maturation (Supplementary Fig. 1). The protocol based on IFN-a proved more effective when differentiating MDDCs from frozen PBMCs, leading to higher cell viability (Supplementary Fig. 2). Moreover, when comparing the phenotypic differentiation profile of DCs, the protocol based on IFN-a was associated with higher expression of the costimulatory molecule CD80 (Supplementary Fig. 3). In light of this evidence, the IFN-a-based protocol was adopted for the present study. Finally, we compared the viability of DCs differentiated after thawing of frozen PBMCs to that of DCs frozen after isolation. Despite its potential advantages in streamlining the protocol, the use of frozen DCs was associated with lower viability and deemed suboptimal for further use (data not shown). 
Overall, these results support the differentiation of MDDCs based on FBS-frozen PBMCs and the use of IFN-a as the optimal protocol for our MDDCT production.

\section{Phenotypic analysis of MDDCs used for MDDCT}

We then examined by flow cytometry the phenotypic characteristics of MDDCs used for MDDCT administration (Fig. 1). The characteristics of the enrolled patients are detailed in Table 1. The gating strategy used for the analysis is depicted in Supplementary Fig. 4. The induction of maturation, a prerequisite of MDDCT administration (Supplementary Fig. 1), was associated, as expected, with increased expression of the activation/maturation markers HLA-DR, CD80, CD86, and CCR7 (Fig. 1). While the expression of CD80 and HLA-DR marks DC activation, but can also be upregulated by tolerogenic DCs, the expression CD83 and CD86 is a marker of mature DCs, supporting the effect of the protocol in specifically inducing DC maturation (55). Moreover, the viability of MDDCs used for MDDCT was similar throughout the three doses administered (median viability $>90 \%$ for all doses) except for a small, albeit significant decrease observed in MMDDCs administered during the second dose (Fig. 2A,B).

\section{Administration of peptide-pulsed MDCCs is associated with T-cell responses.}

Each dose of the autologous, personalized, MDDCT was then administered to 10 chronically HIV-1infected individuals. To evaluate the immunogenicity of MDDCT, we examined by flow cytometry the peptide-specific functional T-cell responses in vitro, following the gating strategy depicted in Supplementary Fig. 5. The results showed increased production, in both $\mathrm{CD}^{+}$and $\mathrm{CD} 8^{+} \mathrm{T}$ lymphocytes, of IFN-y, IL-2, and TNF. This upregulated cytokine production peaked upon administration of dose 3 of the MDDCT and was then reverted during the post-therapy follow-up (Fig. 3). Of note, this increase was not observed in matched positive control samples after stimulation with SEB or in unstimulated samples. (Supplementary Figs. 6,7), thus supporting a specific effect of the MDDCT in inducing response to the peptide stimulus. We also performed qualitative analyses evaluating the number of study volunteers who responded to the MDDCT, comparing the cytokine levels at baseline (day zero) to the cytokine increment on day 15 , day 30 , and day 120 . We chose an arbitrary increase of at least $50 \%$ in the cytokine levels upon MDDCT from baseline to define an MDDCT response and compared the results of in-vitro peptidestimulated and unstimulated cells (Table 2). The analysis showed a significant increase in cytokine production in cells stimulated ex-vivo with Gag-derived peptides compared to unstimulated cells, suggesting a high proportion of immune responders among individuals subjected to MDDCT (Table 2).

To further characterize the immunogenicity of the MDDCT, we evaluated peptide-specific T-cell polyfunctional responses, which have been previously described as correlates of immune control of the infection (56). Polyfunctionality was assessed by flow cytometry in the PBMCs obtained after each MDDCT dose, after $48 \mathrm{~h}$ of cultivation with autologous peptides, using the gating strategy depicted in Supplementary Fig. 5. Our results showed an increase in the frequency of CD $4^{+}$T-lymphocytes characterized by simultaneous expression of at least two of the three cytokines analyzed (i.e., IFN- $y$, IL-2, and TNF) (Fig. 4A). In line with this, within the bulk of the cytokine-producing CD $4^{+}$T-cells, the proportion expressing only one of the three cytokines decreased significantly from the second to the third MDDCT 
dose. A similar, although less evident, result was observed when analyzing CD8 ${ }^{+}$T-cells (Fig. 4B). Although the multiple-comparison post-test (Tukey) could not highlight significant differences over time, the two-way ANOVA test adopted did recognize the positivity to one- or multiple-cytokines as the main source of variation $(P<0.01)$. When the types of cytokines produced by the T-cells were analyzed separately, there was a significant increase in $\mathrm{TNF}^{+} \mathrm{IFN}-\mathrm{Y}^{+} \mathrm{CD} 4^{+} \mathrm{T}$-cells upon dose two as compared to baseline (Fig. 4C). Again, this difference was not visible in CD8 + T-cells (Fig. 4D). To explore whether time on suppressive ART might correlate with MDDCT response, we compared cytokine responses between groups of individuals under long-term suppressive ART (i.e. >10 years of suppressive ART) and individuals under mid/short term suppressive ART (i.e. $<10$ years). The results showed comparable responses between the two groups (Supplementary Fig. 8).

Taken together, these data indicate that MDDCT can evoke peptide-specific immune responses, potentially increasing T-cell polyfunctionality during the MDDCT period.

\section{MDDCT with highly conserved Gag peptides is associated with virologic response}

We then evaluated the virologic response to MDDCT and its possible correlates in order to estimate the feasibility of analytical treatment interruption (ATI) in MDDCT recipients. To this aim, we performed an interim analysis of viral DNA in rectal biopsies (RB) in the individuals subjected to MDDCT. We chose this tissue since DNA in RB strongly correlates with immune-mediated control of viral load in the absence of ART (57). The results showed that two subjects, P26 and P29 from Group 6 (Table 1), displayed undetectable viral DNA in RB. (58). Of note, both subjects had detectable viral DNA in RB at baseline, supporting an effect of the treatment in reducing viral burden. Both individuals with undetectable HIV DNA belonged to the group that had received both the conditioning regimen and the MDDCT (Table 1). However, the difference between the proportion of individuals displaying undetectable viral DNA was not significant between the two groups of MDDCT recipients [Groups 5 and $6(P=0.4286$, intention-to-treat analysis; $\mathrm{P}=0.4444$, per-protocol analysis; Fisher's exact test)]. (58) These analyses (both intention-totreat and per-protocol analysis) were performed to rule out the contribution, to the final result, of two protocol violators (P21 and P30), who, before MDDCT administration, had suspended ART unbeknown to the study investigators.

To understand the correlates of viral DNA abatement, we then analyzed the accuracy of the predictions of NetMHCpan using a newly developed software (Custommune: www.custommune.com; (51)). This software is based on peptide affinity calculations and selects only those peptides in positions corresponding to epitopes validated by biological data for the matched HLA. Interestingly, the subjects displaying undetectable viral DNA were the only two patients whose entire set of peptides was validated by Custommune against biological data for effective HLA binding (LosAlamos database) $(P=0.0157$, intention-to-treat analysis; $\mathrm{P}=0.0350$, per-protocol analysis; Chi-square) (Fig. 5).

\section{Discussion}


The present study shows the feasibility of using a personalized Gag-based MDDCT to increase the adaptive immune response against HIV in patients undergoing suppressive ART for prolonged periods. In particular, epitopes from highly conserved sequences of the Gag region of HIV could be ideal candidates if they are administered following an appropriate conditioning regimen.

A previous report of post-treatment control of viremia in two macaques infected with the HIV homolog SIVmac251 (59) may help clarify the results of the present study. The macaques had received ART in combination with an experimental treatment with immune-modulating drugs. Although the virus was not eradicated, the macaques showed, upon suspension of all therapies, control of viremia, which was associated with anti-Gag cell-mediated immunity (59). The most robust immune responses were directed against an amino acid sequence highly conserved in both human and simian lentiviruses $\left(\mathrm{Gag}_{256-377}\right.$; amino acid numbering is according to the HIV Gag epitope map in the Los Alamos HIV database: https://www.hiv.lanl.gov/content/immunology/maps/ctl/Gag.html; accessed June 8th, 2019). Also, in the present study, the sequences of the epitopes used to immunize the subjects who eventually displayed an undetectable viral DNA mapped to the highly conserved portion of p24 that is homologous to that identified in the post-treatment controller macaques.

Interestingly, the highly conserved sequence of Gag associated with immune control corresponds to a portion of the protein responsible for multimerization. Furthermore, assembly of p24 displays a recursive pattern with the hexamer being the fundamental unit and hexamers of hexamers being necessary for further assembly of the capsid structure (34). Thus, the constraints to which this protein portion is subjected may limit the development of viable immune escape mutants.

It is conceivable that also the conditioning regimen to which the study subjects had been subjected before MDDCT administration eventually contributed to the result obtained. On the other hand, we were not able to correlate the duration time of suppressive ART with MDDCT function.

It is known that immune control of HIV infection correlates with the quality of the specific response of Tlymphocytes to the antigens (19). Thus, HIV elite controllers and slow progressors often display HIVspecific $\mathrm{CD} 8^{+}$T-lymphocytes capable of producing multiple cytokines and capable of proliferating in response to the antigen. In particular, CD4 + T-lymphocytes express high amounts of IFN- $\gamma$ and IL-2 in response to HIV peptides (20). Thus, to measure the immunogenicity of MDDCT, we chose to measure IFN- $y$, IL-2, and TNF intracellularly in $\mathrm{CD}^{+}$and $\mathrm{CD} 8^{+}$T-lymphocytes at baseline and after MDDCT dosing. The number of candidates that increased in vitro the cytokine levels in $\mathrm{CD} 4^{+}$and $\mathrm{CD} 8^{+} \mathrm{T}$ cells upon stimulation with Gag peptides from baseline to days 15 and from baseline to days 30 and days 120 after MDDCT was significant as compared to Gag unstimulated response, providing evidence for immunogenicity of the intervention. Also, the increment of single-cytokine producing cells occurred consistently when IL-2, TNF, and IFN- $\gamma$ were measured in $\mathrm{CD} 4^{+}$and $\mathrm{CD} 8^{+} \mathrm{T}$-cells, showing induction of an immunological reaction to the MDDCT adopted in the present study. The confirmation that MDDCT was associated with immune reactivity resides in the fact that cytokine production occurred after MDDCT. At 120 days after MDDCT, there was a trend to a decrease in the levels of intracellular cytokines levels 
comparable to baseline. The monofunctional analysis of the quantification of interleukins somewhat reinforces the concept that the adaptive immune response to HIV disappears among patients undergoing suppressive ART due to the lack of sustained antigenic presentation, suggesting that the immune reinforcement in these patients was essential for surveillance and elimination of infected cells. In this regard, also the maturation of MDDCs in vitro may have played a role. Thus, the phenotyping and immunogenicity data suggest that the MDDCT adopted in the present study has an immunostimulatory potential to generate an inflammatory cellular response to HIV and can constitute an important additional intervention in strategies aimed at achieving the elimination of the infected cells.

While the correlates of immune protection from HIV-1 progression are not fully understood, polyfunctional immune responses seem to play an important role as suggested by direct evidence on individuals exposed to HIV-1 (60), HIV-1 infected non-progressors (61), and by the association of polyfunctional responses with a lower HIV viral set point (62).

As a weakness in the study's design, we recognize the absence of an immunogenicity analysis between the application of the last MDDCT dose (day 30) and the sample collected on day 120 which would have allowed better evaluation of the effect last MDDCT dose. Moreover, MDDCs displayed significantly increased markers of maturation but not of CD14, which is an important marker of differentiation of these cells. In addition, although intracellular IL-2 levels may be considered a surrogate marker of T cell proliferative ability (63), we have not been able to explore T cell expansion and degranulation markers in this pilot study to further confirm the generation of MDDCT-related memory immune responses. Although there was a trend towards an increase in simultaneous production of at least two of these cytokines after MDDCT administration in $\mathrm{CD} 4^{+}$and $\mathrm{CD} 8^{+}$T-lymphocytes, the numerosity of the treatment group did not allow drawing definitive conclusions on this aspect. Therefore, the limited number of study subjects warrants further testing of the present study in a more significant number of individuals.

\section{Conclusions}

This study establishes a novel clinical workflow for personalized MDDCT aimed at targeting HIV-1 reservoirs using a personalized strategy. This strategy combines each individual's genetic profile and the Gag protein of autologous HIV-1, therefore, providing a proof-of-concept of its potential immunogenicity and efficacy.

\section{Declarations}

\section{Ethics approval and consent to participate.}

The protocol was approved by human subjects review committees (approval $\# 180727$ of December $21^{\text {th }}$ 2013), and all subjects gave written, informed consent.

\section{Consent for publication.}


Authors give consent to AIDS RESEARCH and THERAPY to publish this work upon acceptance.

\section{Availability of data and materials.}

All data and material will be deposited at GitLab and will be available to readers.

\section{Authors' contributions}

RD led the project; RD, TO designed the laboratory study strategies; MB, SS, LG, NP, NC, EC-N, JG, DD, MJ, conducted the experiments; MB. LS performed the flow cytometry data analysis, ILS, JH, AS performed the statistical data analysis and post-hoc bioinformatic analyses; TO, MS, CA-N, RS, AD, LJ, MJ oversaw the implementation of lab experiments; GG, PF, RD attended the patients and performed MDDCT procedures; RD; MJ and MG designed the peptides; RD wrote the manuscript; ILS, JH, AS commented on and edited early versions of the manuscript; all authors have read and approved the final manuscript.

\section{Funding sources}

This work was supported by the Fundação de Amparo à Pesquisa do Estado de São Paulo and the Conselho Nacional de Desenvolvimento Científico e Tecnológico (FAPESP 2013/11323-5; CNPq - 454700 2014-8; CNPq/DECIT 441817/2018-1), and ViiV Healthcare Investigator Sponsored Study (RD). LTS is a recipient of a fellowship from FAPESP (Ref. 2018/12460). I.L.S. acknowledges support from FAPESP (Ref. 19/17461-7).

\section{Competing interests.}

ILS, AS, and RD have a patent application for Dendritic-cell therapy.

\section{Acknowledgments}

We thank all the candidates that participate in this research.

\section{References}

1. Chang JJ, Altfeld M. Innate immune activation in primary HIV-1 infection. J Infect Dis. 2010 October 15th;202 Suppl 2:S297-301.

2. Koup RA, Safrit JT, Cao Y, Andrews CA, McLeod G, Borkowsky W, et al. Temporal association of cellular immune responses with the initial control of viremia in primary human immunodeficiency virus type 1 syndrome. J Virol. 1994 Jul;68(7):4650-5.

3. Lu W, Arraes LC, Ferreira WT, Andrieu J-M. Therapeutic dendritic-cell vaccine for chronic HIV-1 infection [Internet]. Vol. 10, Nature Medicine. 2004. p. 1359-65. Available from: http://dx.doi.org/10.1038/nm1147 
4. Gray CM, Lawrence J, Schapiro JM, Altman JD, Winters MA, Crompton M, et al. Frequency of class I HLA-restricted anti-HIV CD8+ T cells in individuals receiving highly active antiretroviral therapy (HAART). J Immunol. 1999 February 1st;162(3):1780-8.

5. Kalams SA, Goulder PJ, Shea AK, Jones NG, Trocha AK, Ogg GS, et al. Levels of human immunodeficiency virus type 1-specific cytotoxic T-lymphocyte effector and memory responses decline after suppression of viremia with highly active antiretroviral therapy. J Virol. 1999 Aug;73(8):6721-8.

6. Pitcher CJ, Quittner C, Peterson DM, Connors M, Koup RA, Maino VC, et al. HIV-1-specific CD4+ T cells are detectable in most individuals with active HIV-1 infection, but decline with prolonged viral suppression. Nat Med. 1999 May;5(5):518-25.

7. Williams JP, Hurst J, Stöhr W, Robinson N, Brown H, Fisher M, et al. HIV-1 DNA predicts disease progression and post-treatment virological control. Elife. 2014 Sep 12;3:e03821.

8. O’Keeffe M, Mok WH, Radford KJ. Human dendritic cell subsets and function in health and disease. Cell Mol Life Sci. 2015 Nov;72(22):4309-25.

9. Surenaud M, Montes M, Lindestam Arlehamn CS, Sette A, Banchereau J, Palucka K, et al. Anti-HIV potency of T-cell responses elicited by dendritic cell therapeutic vaccination. PLoS Pathog. 2019 Sep;15(9):e1008011.

10. García F, Climent N, Guardo AC, Gil C, León A, Autran B, et al. A dendritic cell-based vaccine elicits T cell responses associated with control of HIV-1 replication. Sci Transl Med. 2013 Jan 2;5(166):166ra2.

11. Lévy $Y$, Thiébaut R, Montes M, Lacabaratz C, Sloan L, King B, et al. Dendritic cell-based therapeutic vaccine elicits polyfunctional HIV-specific T-cell immunity associated with control of viral load. Eur $\mathrm{J}$ Immunol. 2014 Sep;44(9):2802-10.

12. Gay CL, DeBenedette MA, Tcherepanova IY, Gamble A, Lewis WE, Cope AB, et al. Immunogenicity of AGS-004 Dendritic Cell Therapy in Patients Treated During Acute HIV Infection. AIDS Res Hum Retroviruses. 2018 Jan;34(1):111-22.

13. Gay CL, Kuruc JD, Falcinelli SD, Warren JA, Reifeis SA, Kirchherr JL, et al. Assessing the impact of AGS-004, a dendritic cell-based immunotherapy, and vorinostat on persistent HIV-1 Infection. Sci Rep. 2020 March 20th;10(1):5134.

14. Kundu SK, Engleman E, Benike C, Shapero MH, Dupuis M, van Schooten WC, et al. A pilot clinical trial of HIV antigen-pulsed allogeneic and autologous dendritic cell therapy in HIV-infected patients. AIDS Res Hum Retroviruses. 1998 May 1st;14(7):551-60.

15. Ide F, Nakamura T, Tomizawa M, Kawana-Tachikawa A, Odawara T, Hosoya N, et al. Peptide-loaded dendritic-cell vaccination followed by treatment interruption for chronic HIV-1 infection: a phase 1 trial. J Med Virol. 2006 Jun;78(6):711-8.

Page $15 / 26$ 
16. Routy J-P, Boulassel M-R, Yassine-Diab B, Nicolette C, Healey D, Jain R, et al. Immunologic activity and safety of autologous HIV RNA-electroporated dendritic cells in HIV-1 infected patients receiving antiretroviral therapy. Clin Immunol. 2010 Feb;134(2):140-7.

17. Van Gulck E, Vlieghe E, Vekemans M, Van Tendeloo VFI, Van De Velde A, Smits E, et al. mRNA-based dendritic cell vaccination induces potent antiviral T-cell responses in HIV-1-infected patients. AIDS. 2012 February 20th;26(4):F1-12.

18. Macatangay BJC, Riddler SA, Wheeler ND, Spindler J, Lawani M, Hong F, et al. Therapeutic Vaccination With Dendritic Cells Loaded With Autologous HIV Type 1-Infected Apoptotic Cells. J Infect Dis. 2016 May 1st;213(9):1400-9.

19. Jacobson JM, Routy J-P, Welles S, DeBenedette M, Tcherepanova I, Angel JB, et al. Dendritic Cell Immunotherapy for HIV-1 Infection Using Autologous HIV-1 RNA: A Randomized, Double-Blind, PlaceboControlled Clinical Trial. J Acquir Immune Defic Syndr. 2016 May 1;72(1):31-8.

20. Gandhi RT, Kwon DS, Macklin EA, Shopis JR, McLean AP, McBrine N, et al. Immunization of HIV-1Infected Persons With Autologous Dendritic Cells Transfected With mRNA Encoding HIV-1 Gag and Nef: Results of a Randomized, Placebo-Controlled Clinical Trial. J Acquir Immune Defic Syndr. 2016 Mar 1;71(3):246-53.

21. Imamichi H, Dewar RL, Adelsberger JW, Rehm CA, O'Doherty U, Paxinos EE, et al. Defective HIV-1 proviruses produce novel protein-coding RNA species in HIV-infected patients on combination antiretroviral therapy. Proc Natl Acad Sci U S A. 2016 Aug 2;113(31):8783-8.

22. Samer S, Namiyama G, Oshiro T, Arif MS, Cardoso da Silva W, Sucupira MCA, et al. Evidence of Noncompetent HIV after Ex Vivo Purging Among ART-Suppressed Individuals. AIDS Res Hum Retroviruses. 2017 Oct;33(10):993-4.

23. Williams TM. Human leukocyte antigen gene polymorphism and the histocompatibility laboratory. J Mol Diagn. 2001 Aug;3(3):98-104.

24. Kiepiela P, Ngumbela K, Thobakgale C, Ramduth D, Honeyborne I, Moodley E, et al. CD8+ T-cell responses to different HIV proteins have discordant associations with viral load. Nat Med. 2007 Jan;13(1):46-53.

25. Addo MM, Yu XG, Rathod A, Cohen D, Eldridge RL, Strick D, et al. Comprehensive epitope analysis of human immunodeficiency virus type 1 (HIV-1)-specific T-cell responses directed against the entire expressed HIV-1 genome demonstrate broadly directed responses, but no correlation to viral load. J Virol. 2003 Feb;77(3):2081-92.

26. Edwards BH, Bansal A, Sabbaj S, Bakari J, Mulligan MJ, Goepfert PA. Magnitude of functional CD8+ T-cell responses to the gag protein of human immunodeficiency virus type 1 correlates inversely with viral 
load in plasma. J Virol. 2002 Mar;76(5):2298-305.

27. Zuñiga R, Lucchetti A, Galvan P, Sanchez S, Sanchez C, Hernandez A, et al. Relative dominance of Gag p24-specific cytotoxic T lymphocytes is associated with human immunodeficiency virus control. J Virol. 2006 Mar;80(6):3122-5.

28. Jansen CA, Kostense S, Vandenberghe K, Nanlohy NM, De Cuyper IM, Piriou E, et al. High responsiveness of HLA-B57-restricted Gag-specific CD8+ T cells in vitro may contribute to the protective effect of HLA-B57 in HIV-infection. Eur J Immunol. 2005 Jan;35(1):150-8.

29. Julg B, Williams KL, Reddy S, Bishop K, Qi Y, Carrington M, et al. Enhanced anti-HIV functional activity associated with Gag-specific CD8 T-cell responses. J Virol. 2010 Jun;84(11):5540-9.

30. Pace MJ, Graf EH, Agosto LM, Mexas AM, Male F, Brady T, et al. Directly infected resting CD4+T cells can produce HIV Gag without spreading infection in a model of HIV latency. PLoS Pathog. 2012 Jul 26;8(7):e1002818.

31. Graf EH, Pace MJ, Peterson BA, Lynch LJ, Chukwulebe SB, Mexas AM, et al. Gag-positive reservoir cells are susceptible to HIV-specific cytotoxic T lymphocyte mediated clearance in vitro and can be detected in vivo [corrected]. PLoS One. 2013 Aug 7;8(8):e71879.

32. Steers NJ, Peachman KK, McClain SR, Alving CR, Rao M. Human immunodeficiency virus type 1 Gag p24 alters the composition of immunoproteasomes and affects antigen presentation. J Virol. 2009 Jul;83(14):7049-61.

33. Zhao G, Perilla JR, Yufenyuy EL, Meng X, Chen B, Ning J, et al. Mature HIV-1 capsid structure by cryoelectron microscopy and all-atom molecular dynamics. Nature. 2013 May 30;497(7451):643-6.

34. Shytaj IL, Savarino A. Cell-mediated anti-Gag immunity in pharmacologically induced functional cure of simian AIDS: a "bottleneck effect"? [Internet]. Vol. 44, Journal of Medical Primatology. 2015. p. 22740. Available from: http://dx.doi.org/10.1111/jmp.12176

35. Burwitz BJ, Giraldo-Vela JP, Reed J, Newman LP, Bean AT, Nimityongskul FA, et al. CD8+ and CD4+ cytotoxic T cell escape mutations precede breakthrough SIVmac239 viremia in an elite controller. Retrovirology. 2012 Nov 6;9:91.

36. Paiardini M, Müller-Trutwin M. HIV-associated chronic immune activation. Immunol Rev. 2013 Jul;254(1):78-101.

37. Zitvogel L, Apetoh L, Ghiringhelli F, André F, Tesniere A, Kroemer G. The anticancer immune response: indispensable for therapeutic success? J Clin Invest. 2008 Jun;118(6):1991-2001.

38. Benhar M, Shytaj IL, Stamler JS, Savarino A. Dual targeting of the thioredoxin and glutathione systems in cancer and HIV. J Clin Invest. 2016 May 2;126(5):1630-9. 
39. Diaz RS, Shytaj IL, Giron LB, Obermaier B, Della Libera E Jr, Galinskas J, et al. Potential impact of the antirheumatic agent auranofin on proviral HIV-1 DNA in individuals under intensified antiretroviral therapy: Results from a randomised clinical trial. Int J Antimicrob Agents. 2019 Nov;54(5):592-600.

40. Chirullo B, Sgarbanti R, Limongi D, Shytaj IL, Alvarez D, Das B, et al. A candidate anti-HIV reservoir compound, auranofin, exerts a selective "anti-memory" effect by exploiting the baseline oxidative status of lymphocytes. Cell Death Dis. 2013 Dec 5;4:e944.

41. Shytaj IL, Norelli S, Chirullo B, Della Corte A, Collins M, Yalley-Ogunro J, et al. A Highly Intensified ART Regimen Induces Long-Term Viral Suppression and Restriction of the Viral Reservoir in a Simian AIDS Model [Internet]. Vol. 8, PLoS Pathogens. 2012. p. e1002774. Available from: http://dx.doi.org/10.1371/journal.ppat.1002774

42. Samer S, Arif MS, Giron LB, Zukurov JPL, Hunter J, Santillo BT, et al. nicotinamide activates latent HIV-1 ex vivo in ART suppressed individuals, revealing higher potency than the association of two methyltransferase inhibitors, chaetocin and BIX01294. Braz J Infect Dis. 2020 Mar;24(2):150-9.

43. Shytaj IL, Procopio FA, Tarek M, Carlon-Andres I, Tang H-Y, Goldman AR, et al. Glycolysis downregulation is a hallmark of HIV-1 latency and sensitizes infected cells to oxidative stress [Internet]. Available from: http://dx.doi.org/10.1101/2020.12.30.424810

44. Diaz RS, Zhang L, Busch MP, Mosley JW, Mayer A. Divergence of HIV-1 quasispecies in an epidemiologic cluster [Internet]. Vol. 11, AIDS. 1997. p. 415-22. Available from: http://dx.doi.org/10.1097/00002030-199704000-00003

45. Sievers F, Wilm A, Dineen D, Gibson TJ, Karplus K, Li W, et al. Fast, scalable generation of high-quality protein multiple sequence alignments using Clustal Omega. Mol Syst Biol. 2011 Oct 11;7:539.

46. NetMHCpan 4.0 Server [Internet]. [cited 2021 Jul 26]. Available from: http://www.cbs.dtu.dk/services/NetMHCpan-4.0/

47. Automated Server Benchmarks [Internet]. [cited 2021 Jul 26]. Available from: http://tools.iedb.org/auto_bench/mhci/weekly/

48. Dhanda SK, Mahajan S, Paul S, Yan Z, Kim H, Jespersen MC, et al. IEDB-AR: immune epitope database-analysis resource in 2019. Nucleic Acids Res. 2019 Jul 2;47(W1):W502-6.

49. M.T. Custommune [Internet]. [cited 2021 Jul 26]. Available from: https://www.custommune.com

50. Gag CTL/CD8+ Epitope Map [Internet]. [cited 2021 Jul 26]. Available from: https://www.hiv.lanl.gov/content/immunology/maps/ctl/Gag.html

51. Tarek M, Elhefnawi M, Maricato JT, Diaz RS, Shytaj IL, Savarino A. Custommune: a web tool to design personalized and population-targeted vaccine epitopes. medRxiv. 2020 Apr

Page 18/26 
52. Komninakis SV, Santos DEM, Santos C, Oliveros MPR, Sanabani S, Diaz RS. HIV-1 proviral DNA loads (as determined by quantitative PCR) in patients subjected to structured treatment interruption after antiretroviral therapy failure. J Clin Microbiol. 2012 Jun;50(6):2132-3.

53. Buzón MJ, Massanella M, Llibre JM, Esteve A, Dahl V, Puertas MC, et al. HIV-1 replication and immune dynamics are affected by raltegravir intensification of HAART-suppressed subjects. Nat Med. 2010 Apr;16(4):460-5.

54. Kumar AM, Fernandez JB, Singer EJ, Commins D, Waldrop-Valverde D, Ownby RL, et al. Human immunodeficiency virus type 1 in the central nervous system leads to decreased dopamine in different regions of postmortem human brains. J Neurovirol. 2009 May;15(3):257-74.

55. Sim WJ, Malinarich F, Fairhurst A-M, Connolly JE. Generation of Immature, Mature and Tolerogenic Dendritic Cells with Differing Metabolic Phenotypes. J Vis Exp [Internet]. 2016 Jun 22;(112). Available from: http://dx.doi.org/10.3791/54128

56. Ndhlovu ZM, Proudfoot J, Cesa K, Alvino DM, McMullen A, Vine S, et al. Elite controllers with low to absent effector CD8+ T cell responses maintain highly functional, broadly directed central memory responses. J Virol. 2012 Jun;86(12):6959-69.

57. Avettand-Fenoel V, Prazuck T, Hocqueloux L, Melard A, Michau C, Kerdraon R, et al. HIV-DNA in rectal cells is well correlated with HIV-DNA in blood in different groups of patients, including long-term nonprogressors. AIDS. 2008 Sep 12;22(14):1880-2.

58. Viard J-P, Burgard M, Hubert J-B, Aaron L, Rabian C, Pertuiset N, et al. Impact of 5 years of maximally successful highly active antiretroviral therapy on CD4 cell count and HIV-1 DNA level. AIDS. 2004 Jan 2;18(1):45-9.

59. Shytaj IL, Nickel G, Arts E, Farrell N, Biffoni M, Pal R, et al. Two-Year Follow-Up of Macaques Developing Intermittent Control of the Human Immunodeficiency Virus Homolog Simian Immunodeficiency Virus SIVmac251 in the Chronic Phase of Infection. J Virol. 2015 Aug;89(15):7521-35.

60. Website [Internet]. Available

from: https://www.frontiersin.org/articles/10.3389/fimmu.2021.638144/full

61. Polyfunctional CD4+ T cell responses in HIV-1-infected viral controllers compared with those in healthy recipients of an adjuvanted polyprotein HIV-1 vaccine. Vaccine. 2013 Aug 12;31(36):3739-46.

62. Riou C, Burgers WA, Mlisana K, Koup RA, Roederer M, Abdool Karim SS, et al. Differential Impact of Magnitude, Polyfunctional Capacity, and Specificity of HIV-Specific CD8+ T Cell Responses on HIV Set Point. J Virol. 2014 Feb;88(3):1819. 
63. Ross SH, Cantrell DA. Signaling and Function of Interleukin-2 in T Lymphocytes [Internet]. Vol. 36, Annual Review of Immunology. 2018. p. 411-33. Available from: http://dx.doi.org/10.1146/annurevimmunol-042617-053352.

\section{Tables}

Due to technical limitations, table 1 and 2 is only available as a download in the Supplemental Files section.

\section{Figures}


A
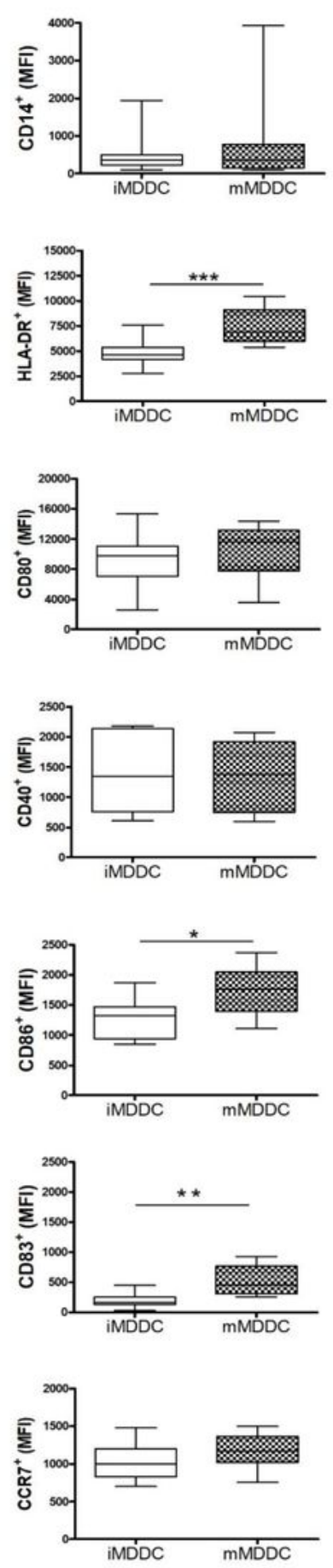

iMDDC = immature monocyte-derived dendritic cells $\mathrm{mMDDC}=$ mature monocyte-derived dendritic cells
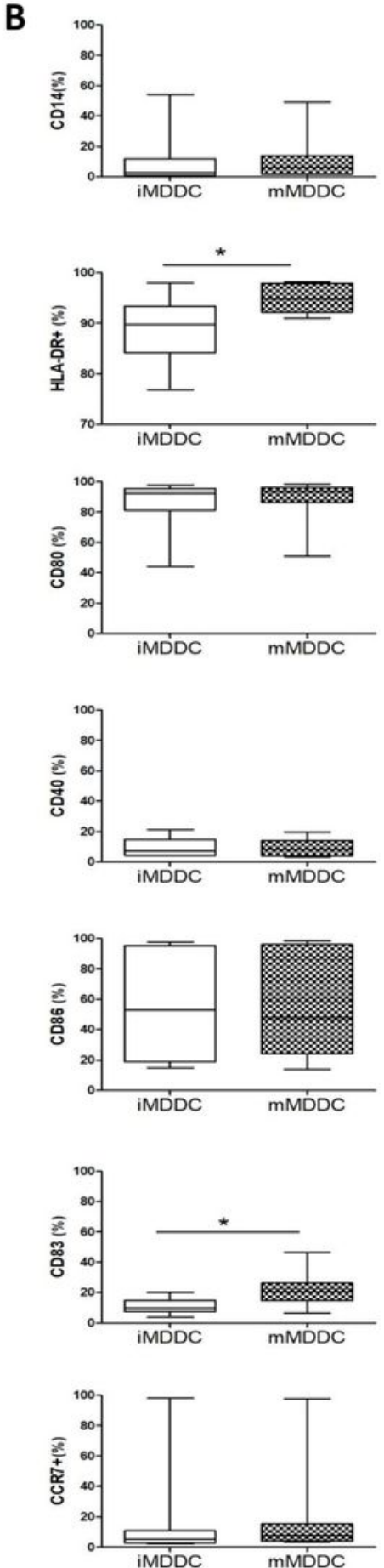

\section{Figure 1}

Phenotypic characterization of immature and mature MDDCs used for MDDCT. Panels A,B) PBMCs were isolated from the total blood of the enrolled individuals and induced to MDDC differentiation/maturation as depicted in Supplementary Figure 1. Both immature MDDCs (iMDDC) and mature MDDCs (mMDDCs) were analyzed by flow cytometry for the expression of the activation/maturation markers HLA-DR, CD80, CD86, CD83, CD40, and CCR7 according to the gating strategy depicted in Supplementary Figure 7A. Box 
plots and whiskers represent the median fluorescence intensity of each marker (A) or the percentage of cells expressing each marker $(B)$. Data are expressed as median $\pm \mathrm{min} / \mathrm{max}$ and were analyzed by the non-parametric Wilcoxon test $(\mathrm{N}$ of patients $=10) .{ }^{\star *} \mathrm{p}<0.01$.

A

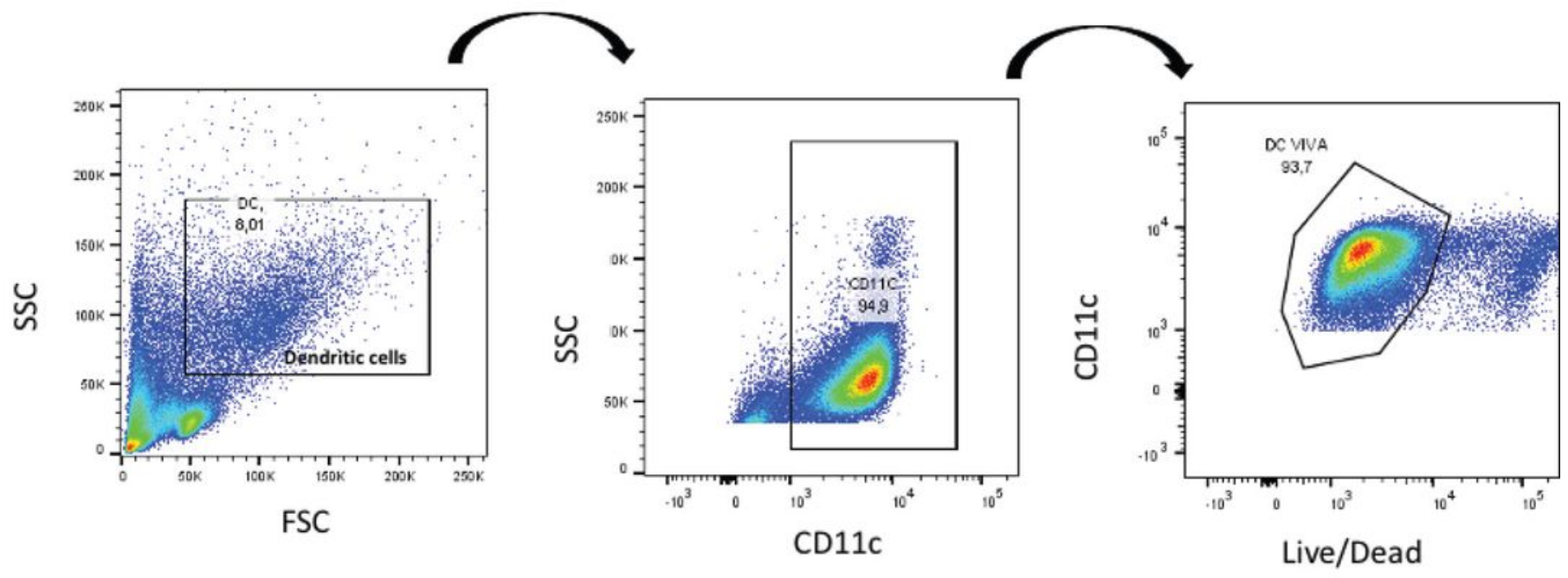

B

n.s.

n.s.

n.s.

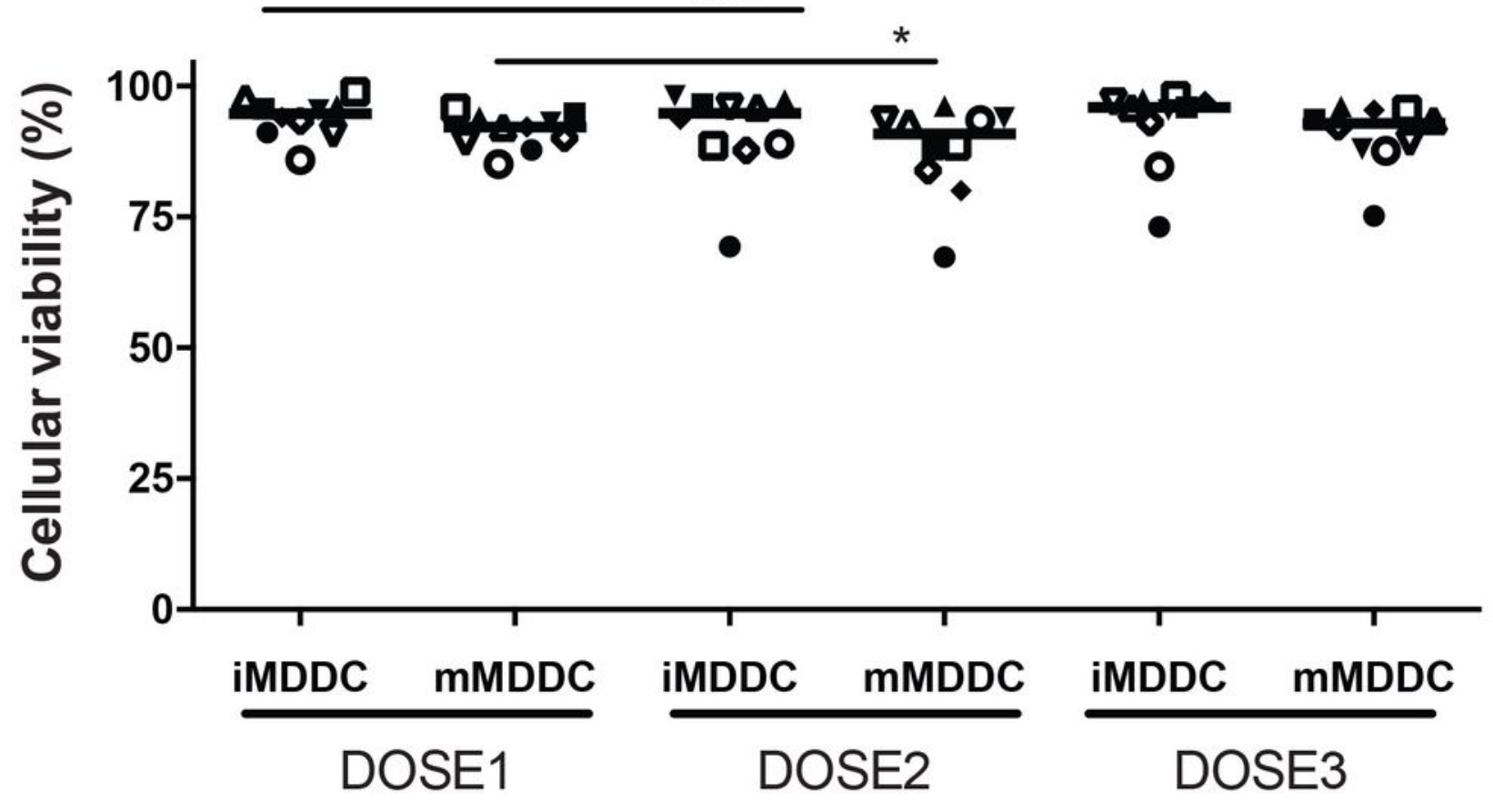

Figure 2

Viability of MDDCs used for each MDDCT dose preparation. Viability was assessed by flow cytometry following staining with a LIVE/DEAD fixable stain according to the gating strategy shown in (A). The 
horizontal line in the graph of panel $\mathrm{B}$ indicates the median ( $\mathrm{N}$ of patients for each dose $=10$ ). Data were analyzed by Two-Way ANOVA. * $p<0.05$.

A
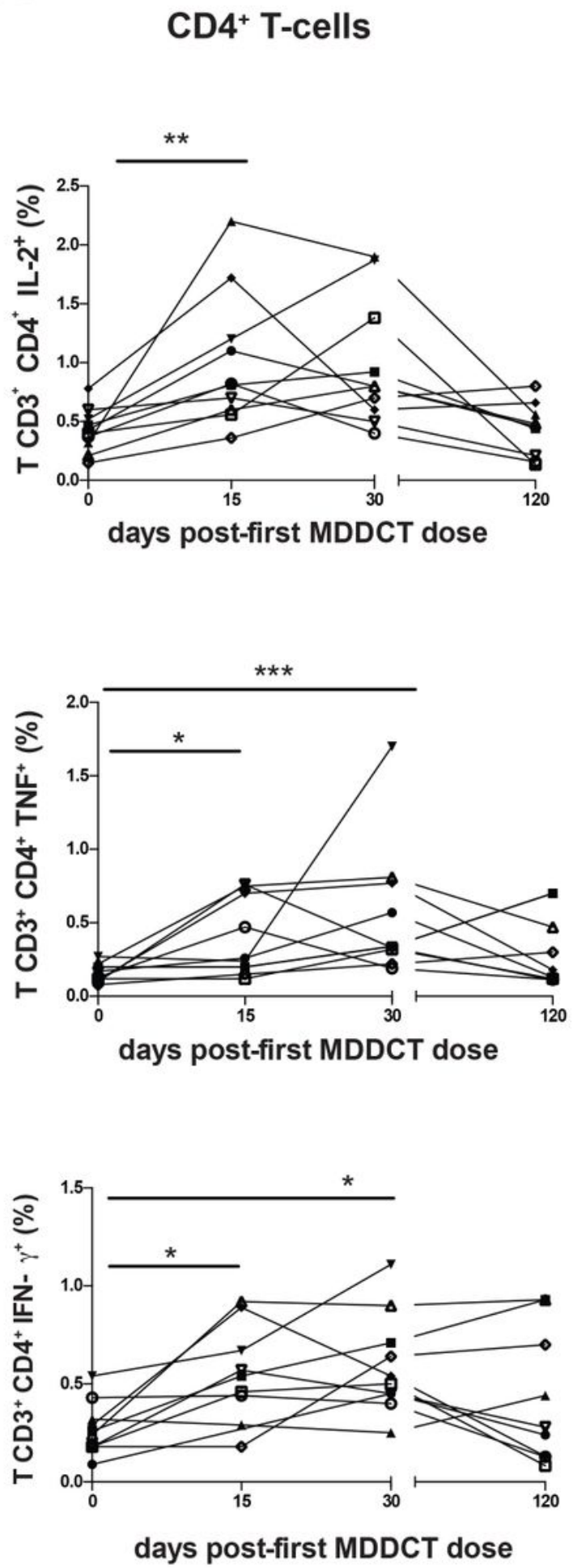

B
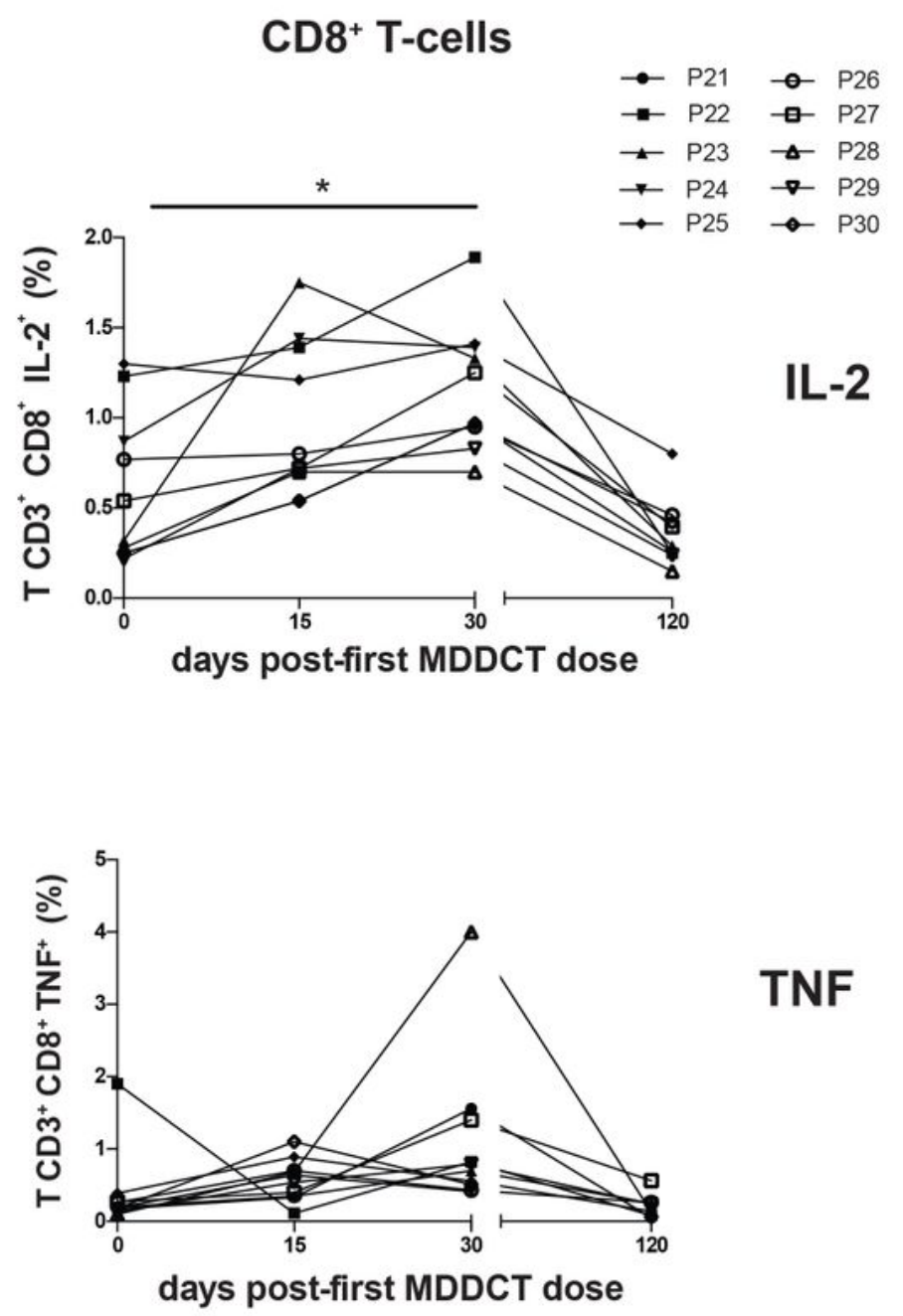

TNF

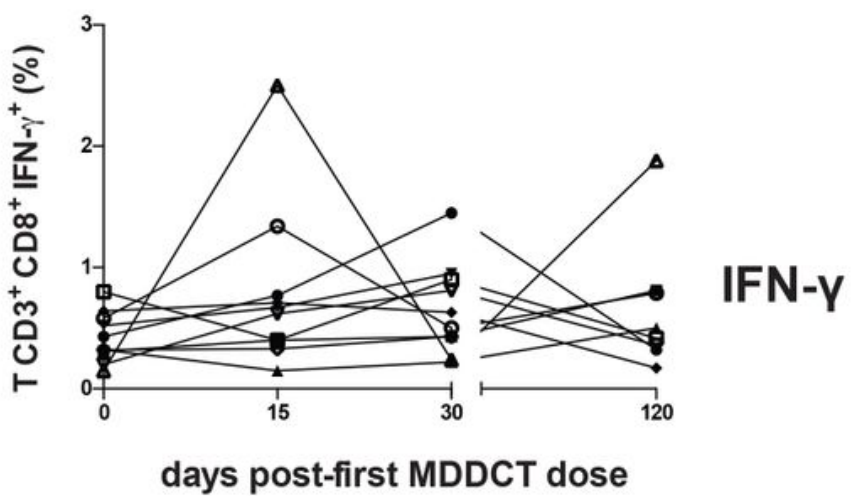

Figure 3

Immunogenicity of MDDCT. Ten recipients (Table 1) received three doses of the personalized MDDCT. PBMCs were collected upon administration of the first MDDCT dose (day 0), upon dose 2 (day 15), and dose 3 administration (day 30), as well as during the post-therapy follow-up (day 120). Isolated PBMCs 
were stimulated in vitro with the autologous Gag peptides that were used for MDDCT. Production of IFN- $y$, IL-2, and TNF by CD4+ and CD8+ T-lymphocytes was evaluated by flow cytometry. After applying the logit transformation to restore normality, data of patients for which all time points were available for a given cytokine were analyzed by one-way ANOVA followed by Dunnet's post-test. ${ }^{\star} p<0.05$; ${ }^{\star \star} p<0.01$; ${ }^{\star \star \star} p<$ 0.001 .

A

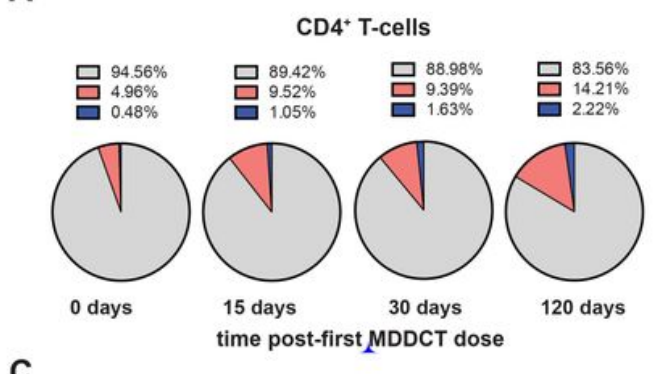

C

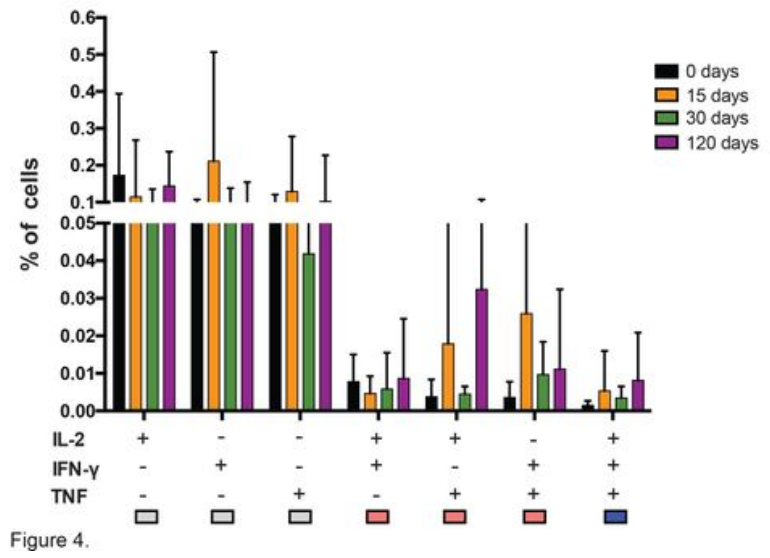

B
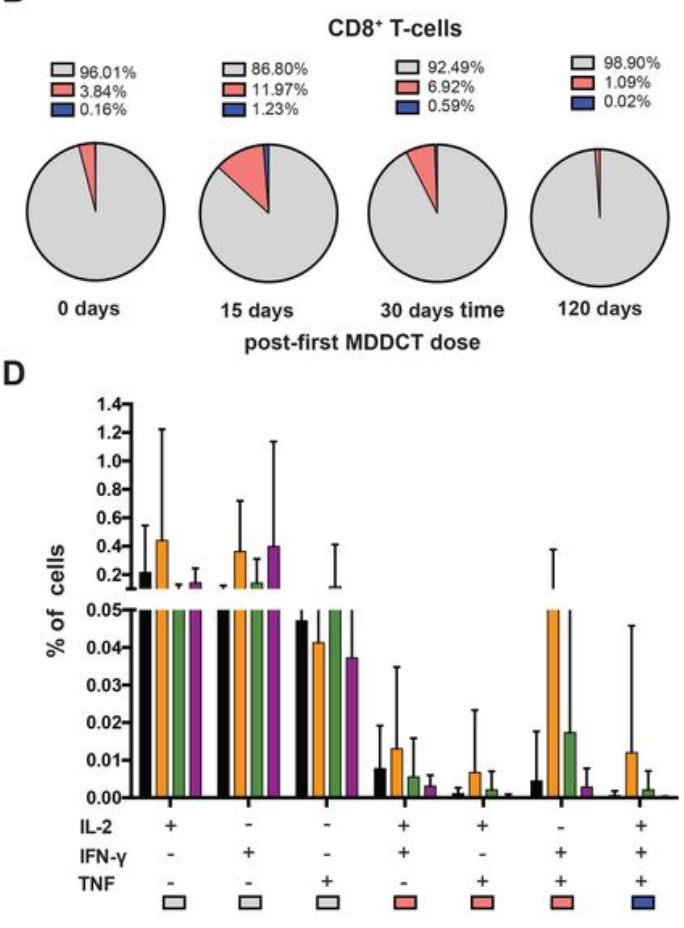

D

Cytokines: IL-2, TNF, IFN-Y

마 to one cytokine + to three cytokines 足 to one cytokine + to two cytokines
+ to three cytokines

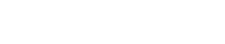


A

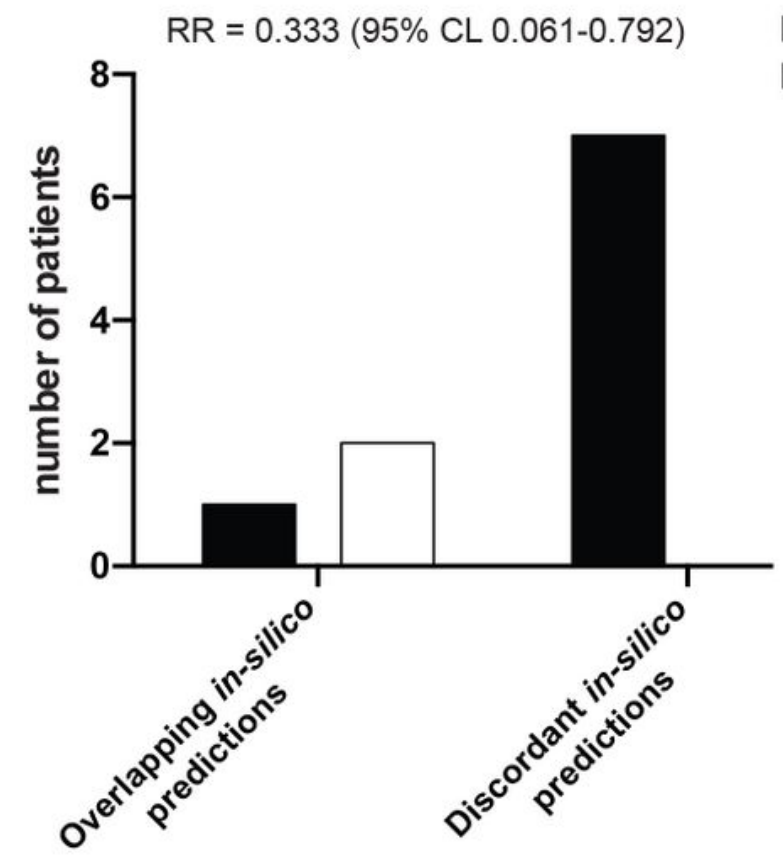

B

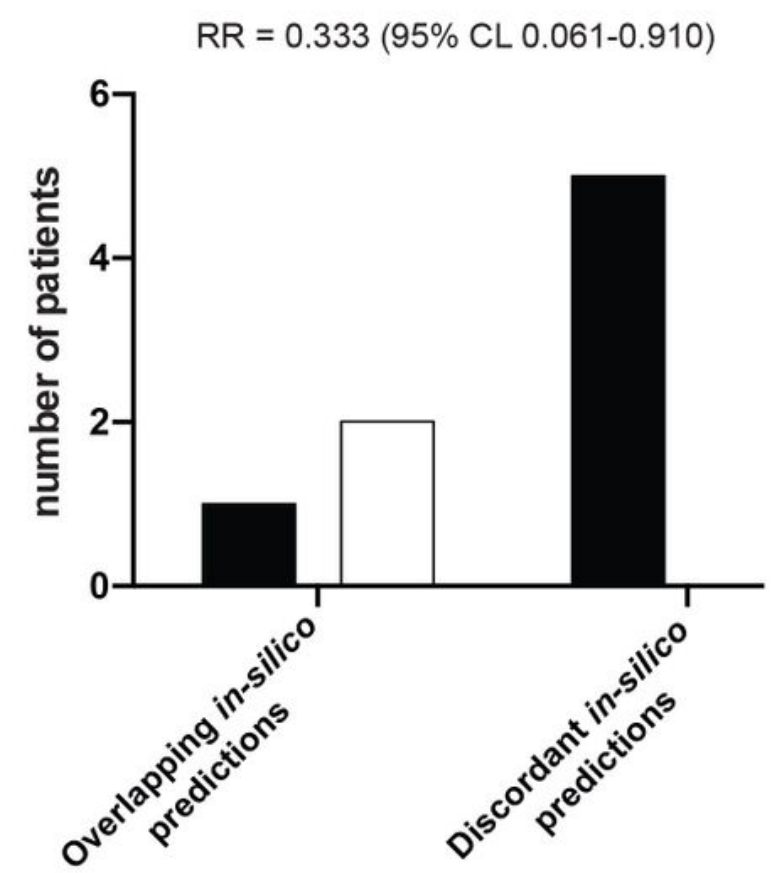

HIV-1 DNA in rectal biopsy

- Detectable

Undectable

\section{Intention to treat}

HIV-1 DNA in rectal biopsy

- Detectable

$\square$ Undectable

\section{Per protocol}

\section{Figure 5}

The proportion of patients displaying an undetectable HIV-1 DNA level in rectal biopsies at the end of all treatments. Panels $A, B)$ MDDCT recipients were subjected to rectal biopsy before all investigational interventions (baseline) and at the end of all treatments. Patients were stratified based on the concordance (or lack thereof, i.e .concordance for $50 \%$ or less of the epitopes administered) of predicted epitopes between the online tools NetMHCpan (http://www.cbs.dtu.dk/services/NetMHCpan/) and 
Custommune (www.custommune.com). The relative risk (RR) is referred to the risk of having detectable viral DNA as calculated by intention-to-treat $(A)$ and per-treatment $(B)$ analysis.

\section{Supplementary Files}

This is a list of supplementary files associated with this preprint. Click to download.

- SupplementaryFigure1.pdf

- SupplementaryFigure2.pdf

- SupplementaryFigure3.pdf

- SupplementaryFigure4.pdf

- SupplementaryFigure5revised.pdf

- SupplementaryFigure6revised.pdf

- SupplementaryFigure7revised.pdf

- SupplementaryFigure8.pdf

- SupplementaryTable1.pdf

- Table2.pdf

- Table1.pdf 